\title{
濃厚 $\mathrm{LiBr}$ 水溶液中における銅の腐食形態と腐食減少量の経時変化† \\ 入江 智芳* 上原 伶祐** 北村 亮裕** 八鍬 浩* 春名 匠***
}

\section{Transients of Corrosion Morphology and Weight Loss of $\mathrm{Cu}$ in Concentrated $\mathrm{LiBr}$ Aqueous Solution}

by

\author{
Tomoyoshi Irie*, Ryosuke UeharA**, Akihiro Kitamura**, \\ Hiroshi Yakuwa* and Takumi HARUnA***
}

\begin{abstract}
This research aimed to investigate transients of corrosion morphology and weight loss of $\mathrm{Cu}$ in concentrated $\mathrm{LiBr}$ aqueous solution for understanding corrosion process of copper parts in an absorption heat pump. Cu plate specimens were immersed in an aqueous solution containing 65 mass $\% \mathrm{LiBr}$ and $0.2 \mathrm{mass} \% \mathrm{LiOH}$ at $353 \mathrm{~K}$ for various times, and then subjected to weight measurement tests and surface analysises. The specimen immersed in the solution suffered pit-like corrosion. The number of the pit increased linearly with an increase in an immersion time until $691.2 \mathrm{ks}$, and thereafter almost no pit was initiated. Each pit was semi-spheroid, and grew at a constant rate in each direction of horizontal and vertical. A corrosion weight loss showed an accelerated increase as an immersion time elapsed. The transients of the weight loss until $1728 \mathrm{ks}$ was successfully simulated by assuming the corrosion process of the initiation and the growth of the pits. The simulation also revealed that a corrosion area was in good agreement with the whole specimen surface in around $1728 \mathrm{ks}$, and then that aspect of the corrosion shifted from pit-like corrosion to general corrosion. The empirical corrosion rate after $1728 \mathrm{ks}$ obtained by the weight measurement test was also in good agreement with the vertical growth rate of the pit.
\end{abstract}

\section{Key words:}

$\mathrm{Cu}$, concentrated $\mathrm{LiBr}$ aqueous solution, $\mathrm{LiOH}$, Corrosion weight loss, Corrosion morphology, Pit-like corrosion, General corrosion

\section{1 緒言}

近年のエネルギー問題や地球規模での環境破壊問題の 観点から, 地域冷暖房をはじめビル・空港等の空調システ ムとして吸収式冷凍機が脚光を浴び，広く使用されるよ うになった ${ }^{1)}$ 。この吸収式冷凍機は高温の濃厚 $\mathrm{LiBr}$ 水溶 液を使用することから，おもな構造材料である炭素鋼と 銅に対する腐食対策が必要である。これまで，高温濃厚 $\mathrm{LiBr}$ 水溶液中における炭素鋼の腐食に関する研究が数多 く行われ, $\mathrm{LiOH}$ の添加や $\mathrm{Li}_{2} \mathrm{MoO}_{4}$ を代表とする各種酸素 酸塩のインヒビターの添加の効果が理解された 2)-8). これ らには，当該水溶液に浸漬した炭素鋼の腐食減少挙動を 把握寸る研究が多く 2),60,9), 電気化学的な腐食挙動の説明 が最近精力的に行われている 10),11)。一方, 当該水溶液中 における銅の腐食挙動に関する研究は比較的少ない。例 えば, $12.45 \mathrm{kmol} \cdot \mathrm{m}^{-3}$ (62 mass\%) $\mathrm{LiBr}+0.145 \mathrm{kmol} \cdot \mathrm{m}^{-3}(0.2$ mass $\%) \mathrm{LiOH}$ 水溶液(433 K)中における炭素鋼，銅，キュ プロニッケルの腐食を抑制するためには $0.03 \mathrm{kmol} \cdot \mathrm{m}^{-3}$ $\mathrm{Na}_{2} \mathrm{~B}_{4} \mathrm{O}_{7}+0.005 \mathrm{kmol} \cdot \mathrm{m}^{-3}$ ベンゾトリアゾールの添加 ${ }^{12) や}$
$0.02 \mathrm{kmol} \cdot \mathrm{m}^{-3} \mathrm{Li}_{2} \mathrm{MoO}_{4}$ の添加 ${ }^{13)}$ が有効であることが示さ れている. その他にも, LiBr 液膜下での銅の腐食挙動 ${ }^{14)}$, 銅イオンおよび腐食生成物の除去技術 ${ }^{15}$, , 炭素鋼との異 種金属接触腐食 16)など，実機操業に有益な情報をもたら す研究のほか, 室温における銅の腐食反応に及ぼす $\mathrm{Br}^{-}$の 影響を理解するための理論的研究 17)-19)が報告されている. そこで本報では、吸収式冷凍機の熱交換器伝熱管に使用 されている銅に濃厚 $\mathrm{LiBr}$ 水溶液中での浸漬腐食試験を行 い, その後の質量測定から, 腐食減少量ならびに皮膜質量 の経時変化を把握すること, ならびに銅試料の表面分析 から得られる腐食形態の経時変化を調査することを目的 とした.

\section{2 方法 \\ $2 \cdot 1$ 試料および試験溶液}

供試材である銅板(純度 $99.96 \%$, 厚さ $2 \mathrm{~mm}$ )を，質量測 定試験用試料として $20 \mathrm{~mm} \times 20 \mathrm{~mm}$ に, 表面分析用試料と して $10 \mathrm{~mm} \times 20 \mathrm{~mm}$ に加工した。 また，浸漬腐食試験に 供するために，いずれの試料の端にも直径 $3.25 \mathrm{~mm}$ の穴

$\dagger$ 原稿受理 令和 2 年 3 月 27 日 Received Mar.27, $2020 @ 2020$ The Society of Materials Science, Japan

* (株)萑原製作所 技術·研究開発統括部 $=251-8502$ 藤沢市本藤沢

Technologies, R\&D, Division, Ebara Corporation, Honfujisawa, Fujisawa 251-8502.

** 関西大学 化学生命工学部 $\bar{T} 564-8680$ 吹田市山手町

Student, Faculty of Chemistry, Materials and Bioengineering, Kansai University, Yamatecho, Suita 564-8680.

*** 正 会員 関西大学 化学生命工学部 テ564-8680 吹田市山手町

Faculty of Chemistry, Materials and Bioengineering, Kansai University, Yamatecho, Suita 564-8680. 
を開けた. 浸漬腐食試験の直前に, 試料全面をエメリー研 磨紙(\#M〜\#6/0)で研磨し, エタノールで脱脂した。

試験溶液には，試薬特級 $\mathrm{LiBr} \cdot \mathrm{H}_{2} \mathrm{O}$ と $\mathrm{LiOH} \cdot \mathrm{H}_{2} \mathrm{O}$ を約 $330 \mathrm{~K}$ の脱イオン水に溶解して調製した $65 \mathrm{mass} \% \mathrm{LiBr}+$ $0.2 \mathrm{mass} \% \mathrm{LiOH}$ 水溶液を使用した。 以降 mass\%を\%に略 記する.

\section{$2 \cdot 2$ 浸漬腐食試験}

試験溶液 $800 \mathrm{~g}$ を約 $330 \mathrm{~K}$ に保持しながらオートクレー ブに入れ, オートクレーブを密閉するとともに, オートク レーブの上蓋から眯架した研磨済み試料を試験溶液に浸 漬した. その後, オートクレーブをヒーターで $333 \mathrm{~K} に$ 保 持しながら油回転型真空ポンプ(ULVAC 製，G-505A)によ り減圧し，オートクレーブと真空ポンプの間に設置した 弁を閉じた。 圧力センサー(横河電機製, FP201A-L31L20AB)によって，オートクレーブ内の圧力がその温度に おける試験溶液の飽和蒸気圧 $(1.2 \mathrm{kPa})$ に保持されている

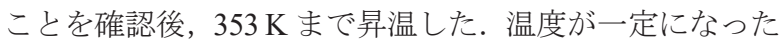
後に, $\mathrm{Ar}$ ガスで大気圧まで加圧し, オートクレーブ内に 空気が侵入しないことを確認しながら $2592 \mathrm{ks}$ までの所定 の時間試料を連続して浸漬し続けた.

\section{$2 \cdot 3$ 表面分析}

浸漬腐食試験が終了した試料の表面および断面の形態 の観察を, 走查型電子顕微鏡 (Scanning Electron Microscope : SEM)(JEOL 製, JSM-6060LV)によって行った. また, この試料の表面に形成した皮膜を $\mathrm{X}$ 線光電子分光 分析(X-ray Photo-Electron Spectroscopy : XPS) (ULVAC-PHI 製，PHI5000 Versaprobe)装置によって分析した．元素分析 用励起 X 線源には Al-Ka 線を使用した. また Ar イオン 銃の加速電圧は $4 \mathrm{kV}$, スパッタリング速度は $\mathrm{SiO}_{2}$ 換算で $20 \mathrm{~nm} \cdot \mathrm{min}^{-1}$ である.

\section{2 - 4 質量測定試験}

浸漬試験が終了した試料を純水およびエタノールで洗 浄してエアースプレーで乾燥させた. その試料を $298 \mathrm{~K} の$ $0.1 \mathrm{kmol} \cdot \mathrm{m}^{-3} \mathrm{H}_{2} \mathrm{SO}_{4}$ 水溶液中に数回浸漬して, 浸漬試験中 に生成した皮膜(スケール)を徐々に溶解除去した. 所定の

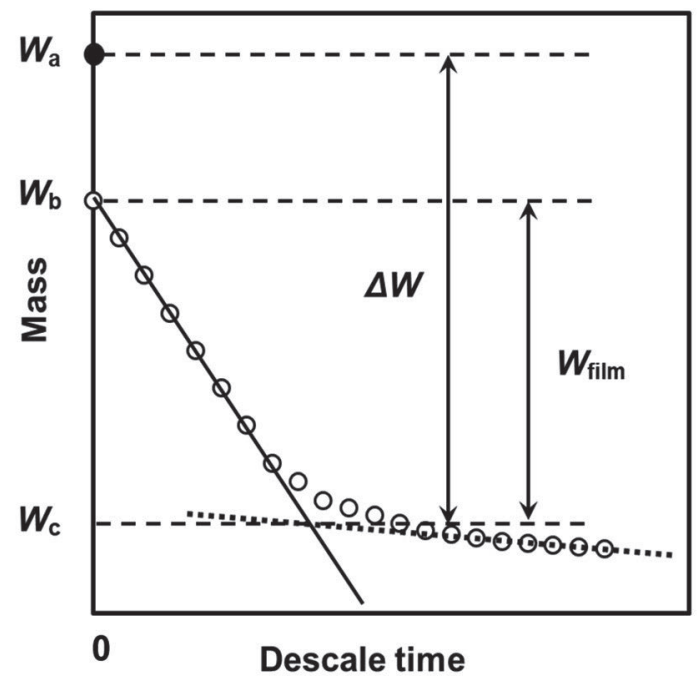

Fig.1 Schematic drawing of change in mass of the specimen during the descaling treatment.

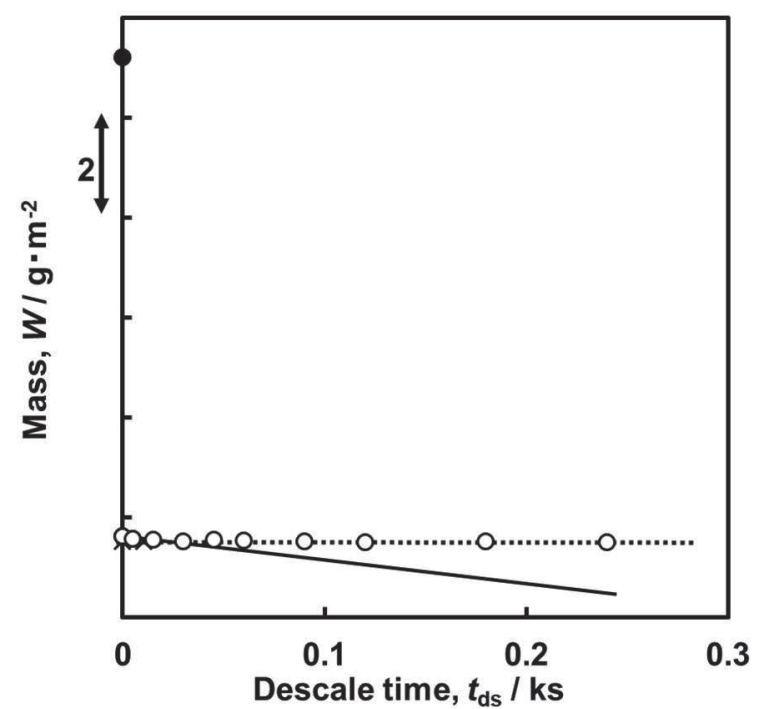

Fig.2 Change in mass of the specimen during the descaling treatment after the immersion corrosion test for $2592 \mathrm{ks}$.

時間脱スケールを行った試料に, CCD カメラ(Charge Coupled Device Camera)による表面観察および電子天科 (AND 製, HR-120，0.01 mg まで測定可能)による質量測定 を行った. Fig.1 に脱スケール時間と試料質量の関係を表 す模式図を示す。ここで $W_{\mathrm{a}}$ は浸漬腐食試験前の試料質量 (時刻 0 の位置に示した○), $W_{\mathrm{b}}$ は浸漬腐食試験後(脱スケ 一ル開始前)の試料質量(時刻 0 の位置に記した○)を示し ている. 試料に対して脱スケール処理, 質量測定を繰り返 すと(任意の脱スケール時間の○)，ある脱スケール時間ま での試験片質量は, 実線で示寸直線に沿って減少し, その 後は実線よりも傾きの小さい点線で示す直線に沿って減 少した. 一方, 皮膜が存在しない浸漬腐食試験前の銅基板 に本脱スケール処理を行うと, その質量は, 処理時間の経 過とともに直線的に減少した．また，その傾きで示される 腐食速度は, Fig.1 に示す点線の傾きから求めた腐食速度 とほぼ一致した。このことから, 実線に沿って試験片質量 が減少している区間では, 腐食により銅基板表面に生成 した皮膜が溶解し, 点線に沿って質量が減少している区 間では，銅基板が溶解していると考えられる．そこで，皮 膜の溶解に関する直線(実線) と, 銅基板の溶解に関する直 線(点線)が重なる点を脱スケール終了点とした. $W_{\mathrm{c}}$ は脱ス ケール終了点における試料質量, $\Delta W$ は浸漬腐食試験によ る銅基板の腐食減少量，W film は皮膜質量をそれぞれ示し ており，これらすべての評価質量は試料表面積で除した 単位面積当たりの值で表した.

\section{3 結果}

\section{$3 \cdot 1$ 浸漬腐食試験後の試料の質量測定試験結果}

$353 \mathrm{~K}$ に保持した $65 \% \mathrm{LiBr}+0.2 \% \mathrm{LiOH}$ 水溶液に 2592 ks 浸漬した試料に対する質量測定試験結果を Fig. 2 に示 す. Fig.1に示した模式図を参照しながら Fig.2 を見ると， 浸漬腐食試験後の試料質量 $(0 \mathrm{ks}$ の位置に示した○)は浸漬 腐食試験前の試料質量 $(0 \mathrm{ks}$ の位置に示したの)から約 10 $\mathrm{g} \cdot \mathrm{m}^{-2}$ 減少した. しかし, 浸漬腐食試験前後の試料の表面 変化は目視では確認できなかった。 脱スケール処理を行 


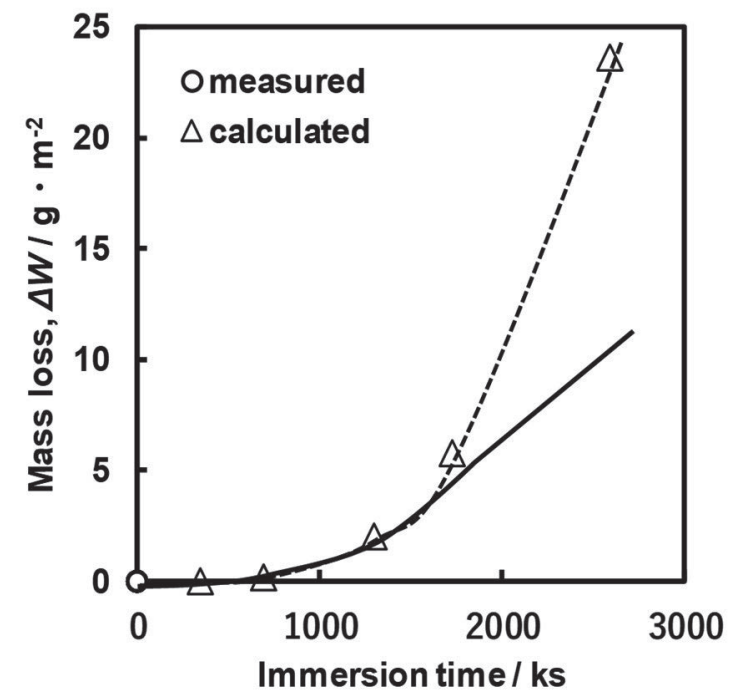

Fig.3 Changes in measured and calculated mass loss of the specimen during the immersion corrosion test.

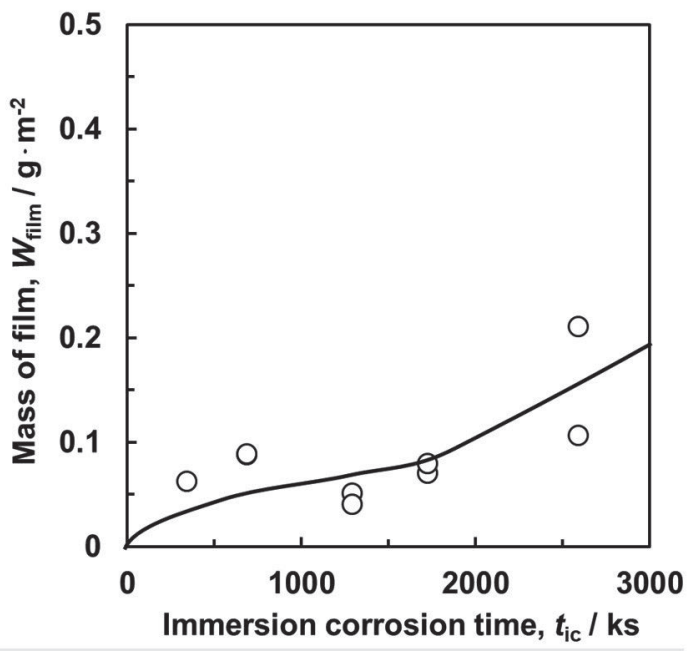

Fig.4 Change in mass of film on the specimen during the immersion corrosion test.

うと，脱スケール時間の経過とともにわずかずつ皮膜の 溶解に関する直線(実線)に沿って質量が減少し，すぐに銅 基板の溶解に関寸る直線(点線)と交わった。浸漬腐食試験 前後の試料の質量差と比較すると, 脱スケール処理によ って得られた皮膜質量は極めて小さいことがわかった。

浸漬腐食試験時間の異なる試料に対して質量測定試験 を実施した。 その結果である, 浸漬腐食試験による銅基板 の腐食減少量の経時変化(図中の○印)を Fig.3 に示す。こ の図より，浸漬時間の経過ともに腐食減少量が加速度的 に増加することがわかった。

一方, 前記質量測定試験の結果得られた, 浸漬腐食試験 中の皮膜質量の経時変化を Fig.4 に示す。この図より，皮 膜質量は浸漬時間の経過とともに徐々に増加し，1728 ks 以降は増加の勾配が大きくなることがわかった。 しかし， $2592 \mathrm{ks}$ 浸漬腐食試験を行った試料に注目すると, 皮膜質 量(約 $0.15 \mathrm{~g} \cdot \mathrm{m}^{-2}$ )が銅基板の腐食減少量(約 $10 \mathrm{~g} \cdot \mathrm{m}^{-2}$ )の約 $1.5 \%$ ときわめて小さいことから, 長時間浸漬腐食試験を 行っても皮膜はほとんど形成されないことがわかった.

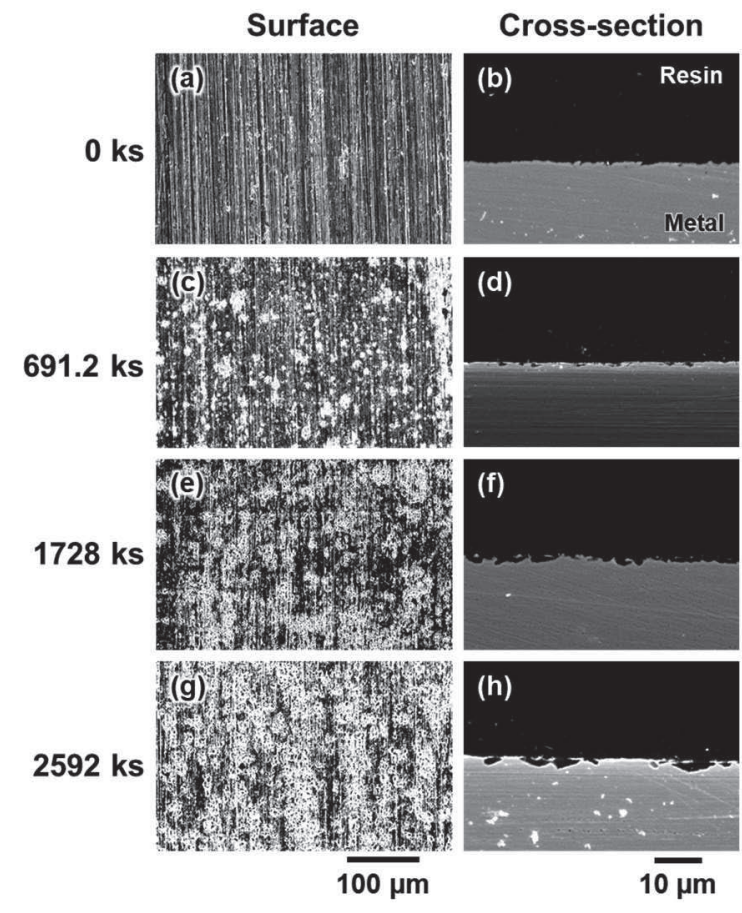

Fig.5 Change of aspects of surface and cross-section of the specimen during the immersion corrosion test.

また, $2592 \mathrm{ks}$ における皮膜を $\mathrm{CuBr}$ と仮定すると, $\mathrm{CuBr}$ の密度 $\left(4.72 \mathrm{Mg} \cdot \mathrm{m}^{-3}\right)$ と皮膜質量から算出した見かけの皮 膜厚さは約 $32 \mathrm{~nm}$ となった. 皮膜を $\mathrm{CuBr}$ と仮定した根拠 は後述する.

\section{$3 \cdot 2$ 浸漬腐食試験後の試料表面・断面分析結果}

浸漬腐食試験中の試料表面形態および断面形態の経時 変化を Fig.5 に示す. 浸漬腐食試験前( $0 \mathrm{ks})$ の試料表面には 微細な研磨傷が確認され, 浸漬時間の経過とともに白色 部が点状に発生し，円に近い形状で拡大した。浸漬時間 $691.2 \mathrm{ks}$ の表面観察では，円に近い形状の白色部が点在し ているが，1728 ks では点在していた円状の白色部が密集 しはじめ, $2592 \mathrm{ks}$ では点在する白色部はほぼなくなった。

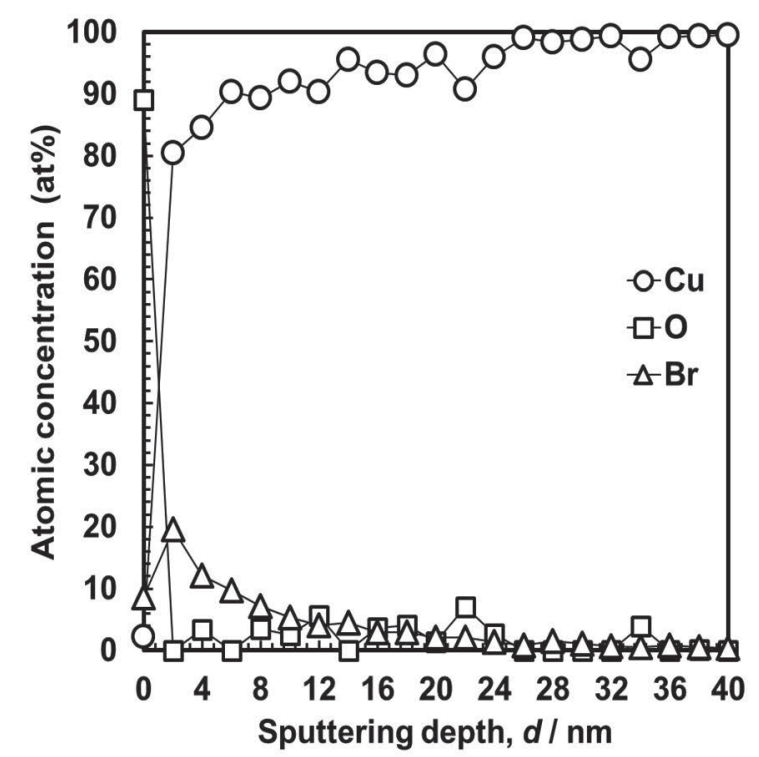

Fig.6 Changes in composition of the film on the specimen 2592 ks after the immersion corrosion test. 

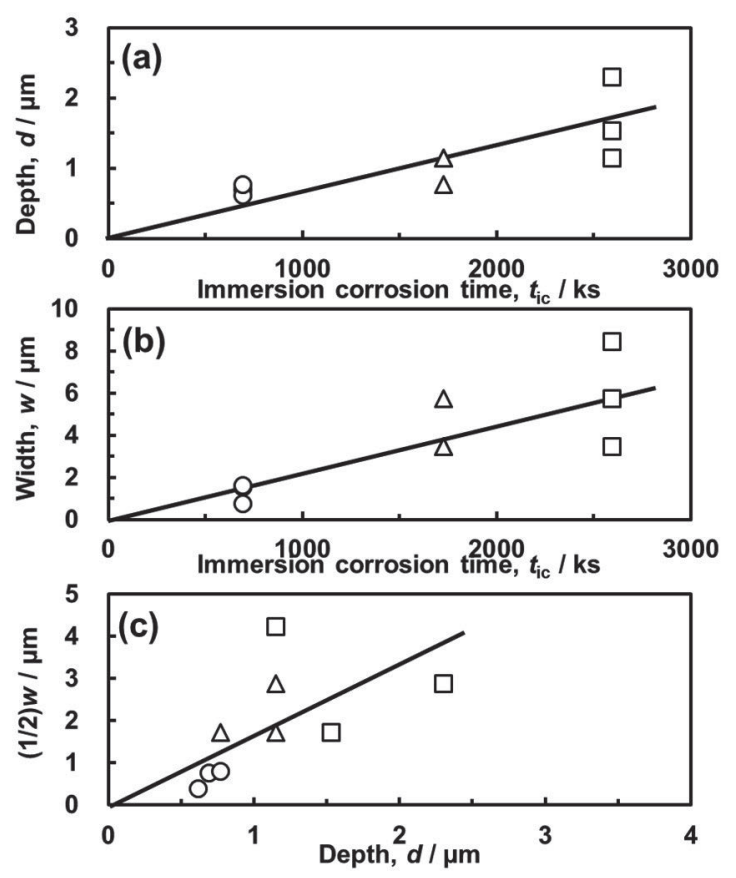

Fig.7 Changes in (a) depth, $d$, and (b) width, $w$, of pit-like corrosion sites on the specimen during the immersion corrosion test, and (c) relationship between $d$ and a half of $w . t_{\mathrm{icc}}: \bigcirc 691.2, \triangle 1728$ and $\square 2592 \mathrm{ks}$.

断面観察からは，点状の白色箇所は孔状の腐食部であり， その孔がほぼ等方的に拡大寸ることが確認された。

浸漬腐食試験後の試料に質量測定試験を行うと, Fig.4 で示す通り極めて薄い皮膜の形成が確認されたので, XPS 分析によって皮膜の調查を行った. $2592 \mathrm{ks}$ 浸漬腐食試験 を行った試料表面からの深さと $\mathrm{Cu}, \mathrm{O}, \mathrm{Br}$ の原子組成比 の関係を Fig.6 に示す。 0 は試料の最表面にのみ極端に多 量に検出されたが，2 nm 以深ではほとんど検出されなか った. 最表面にのみ $\mathrm{O}$ が多量に検出された理由は現在不 明である. $\mathrm{Br}$ は最表面から $2 \mathrm{~nm}$ の位置で最大值を示し, その後 $20 \mathrm{~nm}$ 程度まで検出され, それ以深ではほとんど 検出されず, $\mathrm{Cu}$ のみが検出された. $\mathrm{Br}$ を含む皮膜として は $\mathrm{CuBr}$ と $\mathrm{CuBr}_{2}$ が考えられるが， $\mathrm{CuBr}_{2}$ は水への溶解度 が大きく $\left(55.7 \mathrm{~g} / 100 \mathrm{~g} \mathrm{H}_{2} \mathrm{O}, 293 \mathrm{~K}\right), \mathrm{CuBr}$ は極めて小さい $\left(7.3 \times 10^{-5} \mathrm{kmol} \cdot \mathrm{m}^{-3}, 298 \mathrm{~K}\right)^{20)}$ ので，試料表面には， $\mathrm{CuBr} の$ 皮膜が形成されていると考えられる. $\mathrm{CuBr}$ 皮膜が生成し ているのであれば, XPS の測定值は $\mathrm{Cu}, \mathrm{Br}$ ともに 50 at \% になるべきである。しかしながら，実測值は $\mathrm{Cu}$ が約 80 at \% , Br が約 $20 \%$ となっている.この結果は，皮膜厚さ が光電子の脱出深さよりも薄く, 皮膜下の銅基板の情報 が重畳されたため得られたと考えられる。この状態でス パッタリングをさらに繰り返すと, 皮膜厚さが減少する ために $\mathrm{Br}$ の組成比が減少したと推察される.

\section{4 考察}

Fig.3 に示した浸漬腐食試験中の試料の腐食減少量の経 時変化と Fig.5 に示した試料表面・断面の腐食形態の経時 変化との関連性について検討した.

浸漬腐食試験時間の異なる試料の断面写真から無作為 に選んだ 3 か所の孔状腐食部の最大深さと表面での幅を

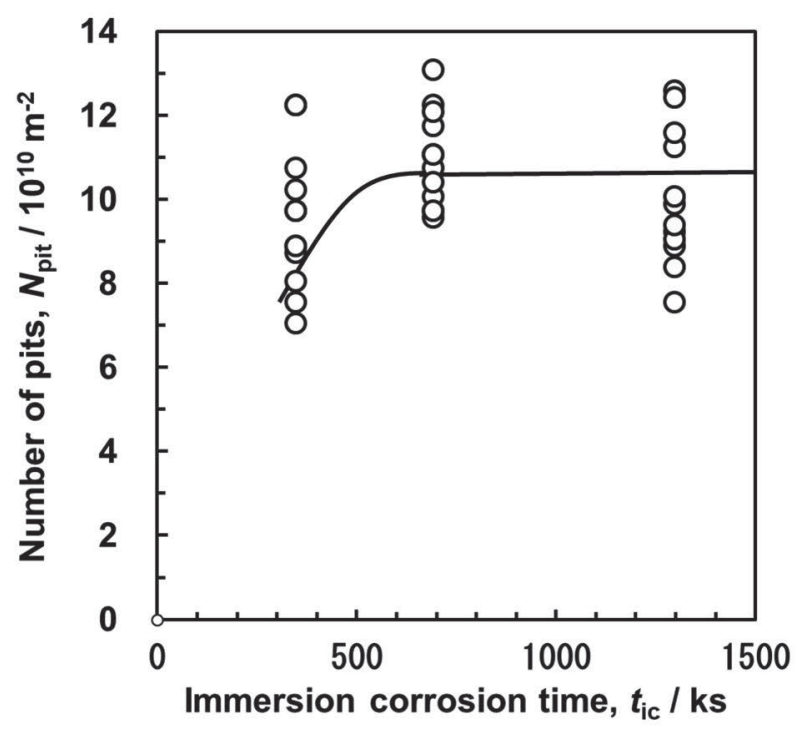

Fig.8 Changes in number of pit-like corrosion sites on the specimen during the immersion corrosion test.

測定した. その結果を Fig.7 に示す. 腐食部の最大深さ(図 (a))には浸漬時間の経過とともに直線的に増加する傾向が 確認され，その進展速度は $6.4 \times 10^{-13} \mathrm{~m} \cdot \mathrm{s}^{-1}$ であった。ま た, 表面での腐食部の幅(図(b))にも浸漬時間の経過ととも に直線的に増加する傾向が確認され, その進展速度は 23.1 $\times 10^{-13} \mathrm{~m} \cdot \mathrm{s}^{-1}$ であった. 一方, Fig.5 に示した浸漬腐食試験 後の試料の断面観察から, 個々の孔状腐食部の形状は半 扁球(半だ円体)であることが推察される. そこで, 扁球の 一方の径である腐食部の幅の $1 / 2$ と他方の径である最大 深さとの関係を検討した. その結果を Fig.7(c)に示す.こ の図より, 個々の腐食部は深さより幅の $1 / 2$ の方が大きな 扁球であることに加えて, 深さに対する幅の $1 / 2$ の割合 (アスペクト比)を 1.62 に保持しながら孔状腐食部が成長 することがわかった.

さらに，浸漬腐食試験時間の異なる試料の表面写真か ら孔状腐食部の個数を測定した。 具体的には, それぞれの 時間浸漬した試験片について，25 $\mu \mathrm{m} \times 25 \mu \mathrm{m}$ の視野にお ける腐食部の個数を 12 ケ所測定し, 単位面積当たりの個 数に換算した. その結果を Fig. 8 に示す. 孔状腐食部の平 均個数は, 浸漬開始から $345.6 \mathrm{ks}$ で $9.5 \times 10^{10} \mathrm{~m}^{-2}$ まで増加 後, $691.2 \mathrm{ks}$ で $11.0 \times 10^{10} \mathrm{~m}^{-2}$ まで緩やかに増加し, $1296 \mathrm{ks}$ で $10.0 \times 10^{10} \mathrm{~m}^{-2}$ となった. $691.2 \mathrm{ks}$ 以降は個数の顕著な 増加が確認されなかった。

これまでに確認した孔状腐食部の形状・進展速度・発生 数の経時変化から, 所定の時間浸漬した試料の腐食減少 量を計算により求める. 腐食減少量を求める時間は, 浸漬 開始後から $172.8 \mathrm{ks}$ を最小単位(浸漬腐食試験の最長試験 時間 $2592 \mathrm{ks}$ を 15 分割したもの)とする. 浸漬開始から $172.8 \mathrm{ks}$ までは腐食部の発生のみで, 腐食部体積は $0 \mathrm{~m}^{3}$ と する(発生時は微小な孔食). $172.8 \mathrm{ks}$ に発生した腐食部が, $345.6 \mathrm{ks}$ まで進展速度に応じて成長した体積から $345.6 \mathrm{ks}$ の腐食減量を計算する。このように, $172.8 \mathrm{ks}$ 毎に発生し た腐食部(微小な孔食)が, 進展速度に応じて成長した体積 


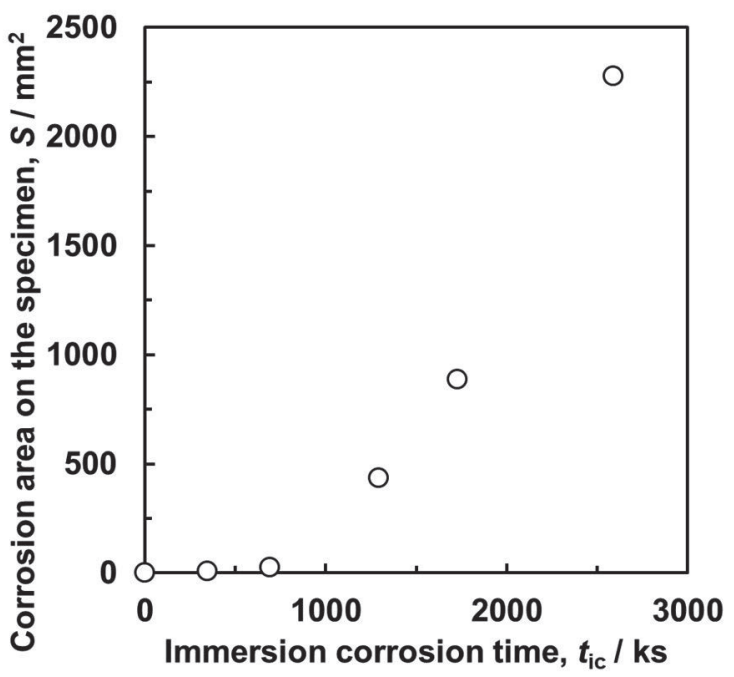

Fig.9 Change in accumulated area of pit-like corrosion sites on the specimen during the immersion corrosion test.

を積算し，腐食減量を求める。まず，Fig.8 に基づいて， 腐食部の発生速度を 3 段階に設定寸る.すなわち 0 ～345.6 $\mathrm{ks}$ では $275 \times 10^{3}$ 個· $\mathrm{m}^{-2} \cdot \mathrm{s}^{-1} ， 345.6 \sim 691.2 \mathrm{ks}$ では $42 \times 10^{3}$ 個. $\mathrm{m}^{-2} \cdot \mathrm{s}^{-1}, 691.2 \mathrm{ks}$ 以降では追加発生なしと仮定する. 次 に、腐食減量を求める時間での腐食部体積は, 扁球の体積 により求める. その体積は, 扁球の長径の $1 / 2$ を半径とす る球の体積を短径に対する長径の比(アスペクト比)で除 した值で表される。したがって, 腐食部の形状と推定した 扁球の半分の体積 $V_{\text {pit }}$ は，その長径である試料表面での腐 食部の幅 $w$ とアスペクト比 $\gamma$ を使用して，次式で与えら れる。

$$
V_{\mathrm{pit}}=\pi w^{3} / 12 \gamma
$$

Fig.7 において, 孔状腐食部の幅の進展速度とアスペクト 比は浸漬腐食試験時間によらずほぼ一定值を示したので, 腐食減量を求める時間における腐食部の体積は，腐食部 発生からの経過時間と進展速度から得られる腐食部の幅 $w$ を用いて(1)式から算出される，以上の手順で， $172.8 \mathrm{ks}$ 毎の腐食部発生数とその経過時間から腐食部の体積を求 めることができ, 基板銅の密度 $\left(8.96 \times 10^{6} \mathrm{~g} \cdot \mathrm{m}^{-3}\right)$ から 172.8 $\mathrm{ks}$ の時間間隔で試料の腐食減少量が算出できる。その結 果を Fig.3 に重䄈て示す．Fig.3 より，1728 ks までは，実 測值と計算值がほぼ合致しているので，孔状腐食の発生， 成長に基づいた腐食減少量の計算方法に対する妥当性が 示された。しかしながら，1728 ks 以降では，実測值より 計算值の方が大きな值を示した。前記腐食減少量の計算 方法では無限の試料表面積を想定したが，実際には有限 $\left(943 \mathrm{~mm}^{2}\right)$ である。前記計算方法を利用して試料表面にお ける腐食面積の経時変化を算出した。その結果を Fig.9に 示す. Fig.9より, $1728 \mathrm{ks}$ 付近で腐食面積の計算值が実際 の試料表面積に到達することがわかった。したがって， $1728 \mathrm{ks}$ 以降では前記計算方法は利用できないことがわか った. 一方，Fig.5(e)に示したように，1728ks では完全な
全面腐食になっていなかった。このことから，1728 ks で は, 非腐食部に孔状腐食の発生, 成長が引き続き起こって いるが，すでに発生した腐食部が周囲の腐食部と連結し ていることも推定される。その結果、幅方向への進展に伴 う腐食は抑制されると考えられる。Fig.3 における浸漬腐 食試験時間が $1728 \mathrm{ks}$ から $2592 \mathrm{ks}$ までの実測腐食減少量 が直線的に増加し, 試料表面が全面均一に腐食したと仮 定したときの銅基板の板厚減少速度は $6.21 \times 10^{-13} \mathrm{~m} \cdot \mathrm{s}^{-1}$ と 算出され，Fig.7(b)から算出された腐食部の最大深さの進 展速度 $6.4 \times 10^{-13} \mathrm{~m}^{\cdot} \mathrm{s}^{-1}$ とほぼ一致した。したがって, 1728 ks 近辺からの腐食減少量は, 幅方向への腐食の寄与が無 視できるほど小さく，互いに連結した腐食部の深さ方向 への腐食によって得られたと考えられる.

ここで， LiBr 水溶液中で銅が皮膜を形成しながら溶解 することについて考察する. まず, 銅がこの水溶液中で溶 解することについて, 板垣ら 17),18)はチャンネルフロー電 極法などの電気化学測定技術を使用して, 室温での $\mathrm{LiBr}$ 水溶液中における $\mathrm{Cu}$ の溶解反応や銅の不均化反応機構な どについて検討し, 自然電位近傍のアノード電流密度が $\mathrm{Br}$ 濃度の増加とともに増加することなどから，本系にお ける $\mathrm{Cu}$ の溶解反応を次のように提案した.

$$
\begin{aligned}
& \mathrm{Cu}+\mathrm{Br}^{-}=\mathrm{CuBr}_{\mathrm{ads}}+\mathrm{e}^{-} \\
& \mathrm{CuBr} \text { ads } \\
& +\mathrm{Br}^{-} \rightarrow \mathrm{CuBr}^{-}
\end{aligned}
$$

また，入江ら ${ }^{19)}$ は $353 \mathrm{~K}$ の $65 \% \mathrm{LiBr}+0.05 \% \mathrm{LiOH}$ 水溶液 中における $\mathrm{Cu}$ の分極曲線に及ぼす $\mathrm{CuBr}$ および $\mathrm{CuBr}_{2}$ 添 加の影響を検討し, $\mathrm{CuBr}$ もくは $\mathrm{CuBr}_{2}$ を 0.02～0.06\% 添加しても, 自然電位近傍のアノード電流密度は $\mathrm{CuBr}$ 濃 度にも $\mathrm{CuBr}_{2}$ 濃度にも影響を受けなかったことを明らか にした。この水溶液には $65 \%$ の $\mathrm{LiBr}$ が溶解しているため

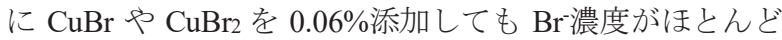
変化しなかったことが板垣らの結果と異なる理由として 挙げられ, 本系における $\mathrm{Cu}$ も(2)式に従ってアノード溶解 することを指摘している. 一方, カソード分極曲線におい て, $\mathrm{CuBr}$ も $\mathrm{CuBr}_{2}$ も添加しない場合には Tafel 勾配を持つ 小さなカソード電流密度が観測されることを明らかにし ている。これらの文献で得られた観測事実と今回行った 浸漬腐食試験で観測された皮膜の存在を考慮すると, $\mathrm{CuBr}$ も $\mathrm{CuBr}_{2}$ も添加しない本試験溶液中においては，自 然電位において(2)式が疑似的に平衡な状態になって表面 に $\mathrm{CuBr}$ が形成されるが，(3)式によって $\mathrm{CuBr}$ が溶解消失 するために，(2)式を疑似的な平衡状態に保ちながら， Cu が溶解し続けることが考えられる。また，この場合におけ る(3)式の反応速度が腐食部最大深さの進展速度である $6.4 \times 10^{-13} \mathrm{~m}^{\cdot} \mathrm{s}^{-1}$ と推察される. 試料に発生した孔状腐食部 の数が $691.2 \mathrm{ks}$ 以上浸漬腐食試験を行っても増加しなか った理由は現在不明である。

\section{5 結訔}

$353 \mathrm{~K}$ に保持された $65 \% \mathrm{LiBr}+0.2 \% \mathrm{LiOH}$ 水溶液中に 0〜2592 ks 浸漬した銅試料に質量測定試験および表面分 析を行った結果，以下の知見を得た. 
・ 本試験溶液中に浸漬した銅には孔状の腐食が発生し， 成長した

・ 試料に $691.2 \mathrm{ks}$ までの浸漬腐食試験を行うと, 腐食時 間の増加とともに孔状腐食部の発生数が増加し，1296 ks まではほとんど増加しなかった。

・ 孔状腐食部は半扁球状であり, 短径および長径方向の 進展速度はほぼ一定であった。

・ $1728 \mathrm{ks}$ までの試料の腐食減少量の実測值の経時変化 は, 孔状腐食部の発生数とその体積の経時変化を考慮 した計算結果と一致した.

・ 前記計算方法に基づいて算出された腐食面積は約 $1728 \mathrm{ks}$ で銅試料の全表面積と一致し，それ以降の実 測質量減少速度から算出される試料厚さの減少速度 は孔状腐食部の最大深さの進展速度とほぼ一致した。

\section{参 考 文 献}

1) S. G. Hyun, K. Saito and S. Kawai, "Dynamic characteristics of the generator for absorption refrigerator", Transactions of the Japan Society of Mechanical Engineers, Series B, Vol.65, No.631, pp.256-263 (1999).

2) K. Tanno, M. Itoh, M. Aizawa, K. Mabuchi and H. Yashiro, "Development of corrosion inhibition technologies in absorption chiller heaters", Zairyo-to-Kankyo, Vol.52, No.5, 236-243 (2003).

3) K. Tanno, M. Itho, H. Sekiya, H. Yashiro and N. Kumagai, "The corrosion inhibition of carbon steel in lithium bromide solution by hydroxide and molybdate at moderate temperatures", Corrosion Science, Vol.34, No.9, pp.14531461 (1993).

4) H. Yashiro, A. Sai, N. Kumagai, K. Tanno and K. Mabuchi, "Corrosion behavior of carbon steel in concentrated LiBr solutions up to 473K", Zairyo-to-Kankyo, Vol.48, No.6, pp.369-374 (1999).

5) K. Aramaki, "Introduction to corrosion inhibitors", Corrosion Engineering, Vol.25, No.11, pp.693-702 (1976).

6) Y. Kojima and S. Tsujikawa, "The critical depth for pits on carbon steel in the concentrated aqueous solution of lithium bromide containing chromate at elevated temperatures", Zairyo-to-Kankyo, Vol.47, No.1, pp.49-57 (1998).

7) Y. Kojima and S. Tsujikawa, "The critical depth for pits on carbon steel in the concentrated aqueous solution of lithium bromide containing nitrate at elevated temperatures", Zairyo-to-Kankyo, Vol.47, No.2, pp.117123 (1998).

8) K. Mabuchi, T. Kikuchi, H. Midorikawa and M. Aiza, "Corrosion inhibition mechanisum of carbon steel by $\mathrm{LiNO}_{3}, \mathrm{Li}_{2} \mathrm{MoO}_{4}$ and $\mathrm{LiNO}_{3} / \mathrm{Li}_{2} \mathrm{MoO}_{4}$ mixed inhibitors in concentrated $\mathrm{LiBr}$ solutions at elevated temperature", Zairyo-to-Kankyo, Vol.45, No.9, pp.526-533 (1996).

9) N. Uedono, H. Nonaka and Y. Sakaguchi, "The development of corrosion inhibitor for stainless steel in the high temperature concentrated aqueous solution of lithium bromide", Journal of the Society of Materials Science, Japan, Vol.50, No.9, pp.1042-1046 (2001).

10) D. Morihashi, T. Irie, Y. Hirohata and T. Haruna, "Influence of concentrations of $\mathrm{LiOH}$ and $\mathrm{Li}_{2} \mathrm{MoO}_{4}$ on polarization curve of carbon steel in concentrated $\mathrm{LiBr}$ solutions", Zairyo-to-Kankyo, Vol.65, No.6, pp.264-268 (2016).

11) T. Irie, D. Morihashi, Y. Hirohata and T. Haruna, "Polarization curves of carbon steel in concentrated $\mathrm{LiBr}$ solutions containing $\mathrm{LiOH}$ and $\mathrm{Li}_{2} \mathrm{MoO}_{4}$ at different temperatures after short immersion", Materials Transactions, on reviewing (2020).

12) Y. Umetsu, K. Tanno and M. Itoh, "Corrosion inhibition of carbon steel, copper and 70/30 cupro-nickel by sodium tetraborate and benzotriazole in concentrated lithium bromide solution at elevated temperature", Corrosion Engineering, Vol.29, No.5, pp.233-238 (1980).

13) M. Itoh, A. Minato, M. Aizawa and K. Tanno, "Corrosion inhibition of carbon steel and cupro-nickel by lithium molybdate in concentrated lithium bromide solution at elevated temperature", Corrosion Engineering, Vol.33, No.9, pp.504-508 (1984).

14) A. Nonaka and H. Nonaka, "Corrosion of copper in a thinsolution layer of concentrated aqueous solution of lithium bromide", Journal of the Society of Materials Science, Japan, Vol.51, No.11, pp.1218-1222 (2002).

15) K. Machizawa, K. Takenaka, Y. Hirata, M. Nagao, N. Ohnaka and M. Itagaki, "Removal techniques of corrosion products in absorption refrigerator", Zairyo-to-Kankyo, Vol.56, No.4, pp.158-164 (2007).

16) K. Mabuchi, T. Kikuchi and H. Takahashi, "Galvanic corrosion between carbon steel and soldering fluxes in a concentrated $\mathrm{LiBr}$ solution at high temperatures", Journal of The Surface Finishing Society of Japan, Vol.49, No.8, pp.875-880 (1998).

17) M. Itagaki, Y. Hirata and K. Watanabe, "Anodic dissolution and disproportional reaction of copper in bromide solution investigated by channel flow electrode", Corrosion Science, Vol.45, No.5, pp.1023-1036 (2003).

18) M. Itagaki, Y. Hirata, K. Watanabe, T. Hishinuma and K. Machizawa, "Electrochemical reactions of copper and carbon steel in lithium bromide solution", Zairyo-toKankyo, Vol.53, No.6, pp.329-336 (2004).

19) T. Irie, H. Yakuwa, T. Oda, Y. Hirohata and T. Haruna, "Influence of environmental factors on corrosion behavior of copper in concentrated lithium bromide solution", Journal of Japan Institute of Copper, on reviewing (2020).

20) Edited by H. Freiser and Q. Fernando, Translated by T. Fujinaga and E. Sekido, "Ion heikou - Bunseki kagaku ni 
okeru", p.250 (1967) Kagaku-dojin Pubublishing

Company, INC. 